\title{
Active Efflux across the Blood-Brain Barrier: Role of the Solute Carrier Family
}

\author{
Hiroyuki Kusuhara and Yuichi Sugiyama \\ Graduate School of Pharmaceutical Sciences, University of Tokyo, Tokyo 113-0033, Japan
}

\begin{abstract}
Summary: The brain uptake of xenobiotics is restricted by the blood-brain brain barrier formed by brain capillary endothelial cells. Active efflux transport systems in the blood-brain barrier work as a detoxification system in the brain by facilitating removal of xenobiotic compounds from the brain. Drugs, acting in the brain, have to overcome such efflux mechanisms to achieve clinically significant concentration in the brain. Multiple transporters are involved in this efflux transport in the brain capillaries. In the past few years, considerable progress has been made in the cloning of these transporters and their functional characterization after heterologous expression. Members of the solute carrier family (SLC) play an important role in the
\end{abstract}

efflux transport, especially for organic anions, which include organic anion transporting polypeptides (OATP/SLCO) and organic anion transporters (OAT/SLC22A). It is believed that coordination of the members of SLC family, and ABC transporters, such as P-glycoprotein, multidrug resistance protein, and breast cancer-resistant protein (BCRP/ABCG2), allows an efficient vectorial transport across the endothelial cells to remove xenobiotics from the brain. In this review, we shall summarize our current knowledge about their localization, molecular and functional characteristics, and substrate and inhibitor specificity. Key Words: Efflux, blood-brain barrier, organic anion transporter, OAT, OATP, ABC transporter.

\section{INTRODUCTION}

Brain capillary endothelial cells (BCEC) are characterized by the paucity of fenestra and pinocytotic vesicles and the highly developed tight junction between adjacent endothelial cells formed by a complex of integral membrane proteins (claudin, occuldin, and junctional adhesion molecules), and peripheral membrane proteins such as zonula occludens proteins. ${ }^{1-3}$ These anatomical features restrict the nonspecific permeation of xenobiotics via the paracellular leakage and allow the BCEC to act as a static wall between the brain and circulating blood. ${ }^{4}$ Due to this barrier function, the brain capillaries are referred to as the blood-brain barrier (BBB). In addition to the BBB, there is another barrier between the CSF and the blood in the ventricles called the blood-CSF barrier (BCSFB). ${ }^{5}$ The capillaries in the choroid plexus, a tiny organ located in the ventricles that produces CSF, are leaky, and compounds in the blood circulation have free access to the basolateral surface of the choroid plexus epithelial cells. However, choroid plexus epithelial cells

Address correspondence and reprint requests to Hiroyuki Kusuhara, Ph.D., 7-3-1 Hongo, Bunkyo-ku, Tokyo 113-0033, Japan. E-mail kusuhara@mol.f.u-tokyo.ac.jp. form a tight monolayer and act as a static wall behind the capillaries of the choroid plexus. Because the transcellular route across the BCEC or choroid plexus epithelial cells is the major pathway for exchanging compounds between the brain and CSF, and blood, compounds with a low intrinsic permeability across the lipid bilayer because of their large molecular weight or high hydrophilicity exhibit poor brain penetration without specific transport systems.

In addition, it is well accepted that active efflux mechanisms at the BBB restrict the brain penetration of xenobiotics. ${ }^{6-9}$ P-glycoprotein (P-gp) is a well-known transporter acting as a gate keeper protein for xenobiotics at the luminal membrane of the BCEC. ${ }^{10,11} \mathrm{P}$-gp is a primary active transporter, so-called $\mathrm{ABC}$ transporter, located on the luminal membrane of the BCEC and extrude hydrophobic neutral and cationic compounds, and certain kinds of organic anions to the blood side. Knockout of the P-gp gene causes a significant increase in the brain concentration of P-gp substrates. ${ }^{11-14}$

Apart from lipophilic compounds, transporters are involved both in uptake and efflux in the transcellular transport from the brain side to the blood-side. A number of transporter genes have been identified during the last decade, and almost 300 genes have been classified into 


\section{Brain side}

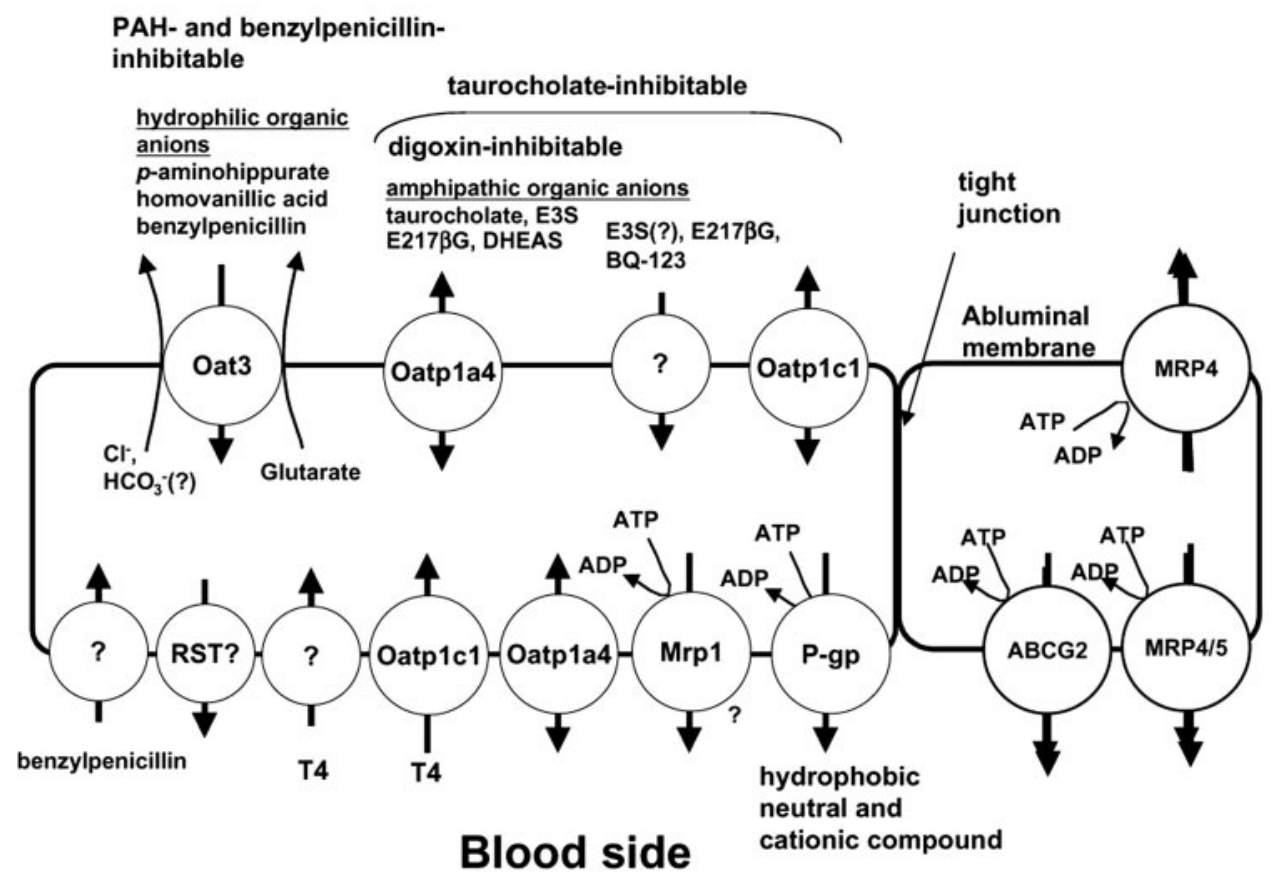

FIG. 1. Schematic diagram of the efflux transport mechanisms at the blood-brain barrier. In vivo experiments employing BEI method has suggested that the efflux mechanism for hydrophilic organic anions is accounted for by Oat3, and that for amphipathic organic anions is accounted for partly by Oatp1a4 (taurocholate- and digoxin-inhibitable pathway) and partly by unknown transporter. The unknown transporter is involved in the efflux of E3S, E217ßG, and BQ-123. On the luminal membrane, Oatp1a4 and Oatp1c1 are involved in the uptake of amphipathic organic anions and peptide, and thyroxine (T4). E3S = estrone-3-sulfate; E217 $\beta \mathrm{G}=$ estradiol 17 $\beta$ glucuronide.

43 families of the solute carrier (SLC) family (the list is available from the web site of BIOPARADIGMS URL: http://www.gene.ucl.ac.uk/nomenclature/). The details of the SLC members are available in the special issue of the European Journal of Physiology (volume 447, no. 5, 2004). The members of the SLCO/SLC21 and SLC22A family are characterized by their multispecificity and have been identified at the BBB. Cumulative studies have demonstrated that they play important roles in the efflux transport of organic compounds, especially organic anions, across the BBB. Fig 1 illustrates the efflux transport mechanisms at the BBB. The present manuscript focuses on the role of members of the SLCO/ SLC21 and SLC22 in efflux transport at the BBB, which are summarized in Table 1.

\section{SLCO/SLC21}

Currently, the SLCO/SLC21 family includes fourteen members in rodents and human. Review articles of the Oatp/OATP family are available. ${ }^{15,16}$ Of the fourteen members, Oatp1a4, Oatp1a5, and Oapt1c1, have been shown to be expressed in the brain capillaries (Table 1).

The molecular characteristics of Oatp1a4 and Oatp1a5

Oatp1a4 was originally isolated from brain and retina cDNAs using homology cloning. ${ }^{17,18}$ The cDNA con- sists of 661 amino acids with an apparent molecular mass of $92 \mathrm{kDa}$, and hydropathy plot analysis predicts 12 putative transmembrane domains. Northern blot analysis revealed abundant expression in the brain where it is widely expressed. ${ }^{17,18}$ Gao et al. ${ }^{19}$ used an immunofluorescence method to show that its membrane localization was on both the luminal and abluminal membrane of the brain capillaries, and on the basolateral membrane of the choroid plexus epithelial cells.

Functional expression in Xenopus laevis oocytes and mammalian cells has revealed its broad substrate specificity including amphipathic organic anions such as bile acids and steroid conjugates, cardiac glycosides such as digoxin and ouabain, and bulky organic cations, such as N-(4,4-azo-n-pentyl)-21-deoxyajmalinium, N-methylquinidine, $\mathrm{N}$-methyl-quinine and rocuronium, as well as anionic peptides, such as BQ-123, [D-Pen2,D-Pen5] enkephalin and deltorphin II. ${ }^{17,18,20-22}$ The driving force for rOatp1a4-mediated uptake remains unknown. Li et al. ${ }^{23}$ demonstrated that rOatp1a4-mediated transport exhibited trans-stimulation. Taurocholate uptake by oocytes expressing rOatp1a4 was increased in the presence of an outward concentration gradient of taurocholate, glutathione and its conjugates, and thus, glutathione is one candidate for the driving force. Conversely, the efflux of dinitropheny-glutathione was increased in oocytes expressing Oatp1a4 compared with that in control 
TABLE 1. Members of SLCO/SLC21A and SLC22A Families Expressed in the BBB and BCSFB

\begin{tabular}{|c|c|c|c|c|c|c|c|}
\hline Name & $\begin{array}{c}\text { Gene } \\
\text { Symbc }\end{array}$ & Species & LocusID & OMIM & $\begin{array}{c}\text { Tissue } \\
\text { Distribution }\end{array}$ & $\begin{array}{l}\text { Membrane } \\
\text { Localization }\end{array}$ & Transport Mechanism \\
\hline \multicolumn{8}{|c|}{ SLCO/SLC21A family } \\
\hline Oatp1a4 & Slcola4 & Rat & 170698 & & $\mathrm{li}, \mathrm{b}, \mathrm{r}, \mathrm{bc}, \mathrm{cp}$ & $\begin{array}{c}\text { SM(li), LM/ } \\
\text { AM(bc), } \\
\text { BLM(cp) }\end{array}$ & ND \\
\hline Oatp1a5 & Slcola5 & Rat & 80900 & & $\begin{array}{l}\mathrm{k}, \mathrm{r}, \mathrm{b}, \mathrm{bc}, \mathrm{lu} \\
\mathrm{si}, \mathrm{cp}\end{array}$ & $\begin{array}{l}\text { BBM (si, } \\
\text { cp) }\end{array}$ & ND \\
\hline OATP1A2 & SLCO1A2 & Human & 6579 & 602883 & $\begin{array}{l}\text { b, bc, Low: k, } \\
\text { li, lu, t }\end{array}$ & $\mathrm{LM} / \mathrm{AM}(\mathrm{bc})$ & ND \\
\hline Oatp1c1 & Slcolcl & Rat & 84511 & & $\mathrm{~b}, \mathrm{bc}, \mathrm{cp}$ & $\begin{array}{l}\text { LM/ } \\
\text { AM(bc), } \\
\text { BLM (cp) }\end{array}$ & ND \\
\hline OATP1C1 & $S L C O 1 C 1$ & Human & 53919 & & $\mathrm{~b}, \mathrm{t}$ & ND & ND \\
\hline \multicolumn{8}{|l|}{ SLC22A family } \\
\hline Oat1 & Slc22a6 & Rat & 29509 & & $\mathrm{k}$ & BLM(k) & OA/dicarboxylate antiport \\
\hline OAT1 & SLC22A6 & Human & 9356 & 607582 & $\mathrm{k}, \mathrm{cp}$ & $\mathrm{BLM}(\mathrm{k})$ & ND \\
\hline Oat3 & Slc $22 a 8$ & Mouse & 19879 & & $\mathrm{k}$ & ND & ND \\
\hline Oat3 & Slc $22 a 8$ & Rat & 83500 & & $\begin{array}{l}\text { li (male), k, } \\
\text { b, e, cp }\end{array}$ & $\begin{array}{l}\text { BLM(k), } \\
\text { AM (bc), } \\
\text { BBM(cp) }\end{array}$ & OA/dicarboxylate antiport \\
\hline OAT3 & SLC22A8 & Human & 9376 & 607581 & $\mathrm{k}, \mathrm{cp}$ & $\mathrm{BLM}(\mathrm{k})$ & OA/dicarboxylate antiport \\
\hline Octn2 & Slc $22 a 3$ & Mouse & 20520 & & Ubiquitously & ND & $\begin{array}{l}\mathrm{Na}^{+} \text {symport (carnitine) } \\
\mathrm{H}^{+} \text {antiport (OC) }\end{array}$ \\
\hline Octn2/CT1 & Slc22a3 & Rat & 29504 & & Ubiquitously & ND & $\begin{array}{l}\mathrm{Na}^{+} \text {symport (carnitine) } \\
\mathrm{H}^{+} \text {antiport }(\mathrm{OC})\end{array}$ \\
\hline OCTN2 & $S L C 22 A 3$ & Human & 6581 & 603377 & Ubiquitously & ND & $\begin{array}{l}\mathrm{Na}^{+} \text {symport (carnitine) } \\
\mathrm{H}^{+} \text {antiport }(\mathrm{OC})\end{array}$ \\
\hline RST & Slc22al2 & Mouse & & & $\mathrm{k}, \mathrm{bc}, \mathrm{cp}$ & BBM (k) & $\begin{array}{l}\text { facilitative (OA), ex- } \\
\text { changer (urate) }\end{array}$ \\
\hline URAT1 & $S L C 22 A 12$ & Human & 116085 & 607096 & $\mathrm{k}$ & BBM (k) & exchanger (urate) \\
\hline
\end{tabular}

The old nomenclature of SLCO/SLC21 listed in this table is as follows: Oatp1a4, Oatp2; Oatp1a5, Oatp3; OATP1A2, OATP or OATP-A; Oatp1c1, Oatp14; OATP1C1, OATP-F.

$\mathrm{li}=$ liver; $\mathrm{b}=$ brain; $\mathrm{r}=$ retina; $\mathrm{bc}=$ brain capillary; $\mathrm{cp}=$ choroid plexus; $\mathrm{k}=$ kidney; $\mathrm{lu}=$ lung; $\mathrm{si}=$ small intestine; $\mathrm{t}=$ testis; $\mathrm{e}=$ eye; $\mathrm{SM}=$ sinusoidal membrane; $1 \mathrm{~m}=$ luminal membrane; $\mathrm{AM}=$ abluminal membrane; $\mathrm{BLM}=$ basolateral membrane; $\mathrm{BBM}=$ brush border membrane; $\mathrm{ND}=$ not determined; $\mathrm{OA}=$ organic anion; $\mathrm{OC}=$ organic cation.

oocytes or oocytes expressing Oatp1, suggesting the possibility that Oatp1a4 mediates efflux as well as uptake across the plasma membrane. ${ }^{23}$

Oatp1a5 was cloned from the rat retina cDNA library, the cDNA of which consist of 670 amino acids with a molecular mass of $80 \mathrm{kDa} .{ }^{17}$ An RNase protection assay revealed its expression in the brain, small intestine, lung, and retina. ${ }^{24} \mathrm{Li}$ et al. ${ }^{25}$ quantified the Oatpla5 mRNA expression and found abundant expression in the lung, cerebellum, and female cerebral cortex and, to a lesser extent, in the intestine. RT-PCR analyses have shown that Oatp1a5 is expressed in the blood-brain barrier, and choroid plexus. ${ }^{26,27}$ Its membrane localization in the brain capillaries remains unclear although immunofluorescence was found to be associated with brain capillaries. ${ }^{27}$ Oatp1a5 is localized on the brush border membrane of the choroid plexus epithelial cells and responsible for the uptake of amphipathic organic anions from the $\mathrm{CSF}^{26}$ Functional expression studies of Oatp1a5 revealed its broad substrate specificity for am- phipathic organic anions, such as bile acids and steroid conjugates, and thyroid hormones. ${ }^{17,24,26,28}$

There is only one human isoform (OATP1A2) that shows relatively high homology to rodent isoforms such as Oatp1a4 and Oatp1a5. OATP1A2 is predominantly expressed in the brain where it is ubiquitously distributed, and to lesser extent, in the lung, liver, kidney, and testis. ${ }^{29}$ Immunofluorescence studies have suggested its expression at human brain capillary endothelial cells, although the membrane localization of OATP1A2 at the human BCEC remains unclear. ${ }^{21}$ The substrate specificity of hOATP1A2 is broad and includes amphipathic organic anions, type II organic cations, and peptides such as [D-penicillamine2,5] enkephalin and deltorphin II. ${ }^{21,30,31}$

\section{The efflux transport of amphipathic organic anions (Oatp substrates) across the BBB}

Leininger et al. ${ }^{32,33}$ have demonstrated a saturable efflux of 1-naphtyl $17 \beta$-glucuronide and a cyclic peptide, RC-160 (a somatostatin analog) by measuring the re- 
TABLE 2. Uptake and Efflux Clearance across the BBB

\begin{tabular}{|c|c|c|c|c|c|c|c|c|}
\hline \multirow[b]{2}{*}{ Compound } & \multicolumn{4}{|c|}{ Efflux } & \multicolumn{2}{|l|}{ Uptake } & \multicolumn{2}{|c|}{ Transporters } \\
\hline & $\underset{\min ^{-1}}{\mathrm{k}_{\text {eff }}}$ & $\begin{array}{c}\mathrm{Vd} \\
\mathrm{ml} / \mathrm{g} \text { brain }\end{array}$ & $\begin{array}{c}\mathrm{CL}_{\text {eff }} \\
\mu \mathrm{l} / \mathrm{min} / \mathrm{g} \text { brain }\end{array}$ & $\begin{array}{c}\mathrm{K}_{\mathrm{m}} * \\
\mu \mathrm{M}\end{array}$ & $\underset{\mu \mathrm{l} / \mathrm{min} / \mathrm{g}}{\mathrm{CL}_{\text {up }}}$ & $\begin{array}{l}\mathrm{K}_{\mathrm{m}} \\
\mu \mathrm{M}\end{array}$ & & $\begin{array}{l}\text { (rodents) } \\
\mu \mathrm{M}\end{array}$ \\
\hline \multicolumn{9}{|l|}{ Organic anions } \\
\hline Taurocholate ${ }^{34}$ & 0.0233 & & & 65.3 & $\begin{array}{l}\text { Below limit of } \\
\text { detection }\end{array}$ & & Oatp1a4 & $35^{17}, 187^{38}$ \\
\hline $\begin{array}{l}\text { Homovalinic } \\
\text { acid }^{52}\end{array}$ & 0.0169 & & & 298 & & & $\begin{array}{l}\text { Oatp1a5 } \\
\text { Oat3 }\end{array}$ & $\begin{array}{c}20^{17}, 30^{24} \\
274^{52}\end{array}$ \\
\hline $\mathrm{PAH}^{51}$ & 0.0587 & 0.8 & 47.0 & 396 & 12.1 & & $\begin{array}{l}\text { Oat3 } \\
\text { Oat3 }\end{array}$ & $\begin{array}{l}65^{50}, 400^{55} \\
65^{50}, 400^{55}\end{array}$ \\
\hline $\begin{array}{l}\text { PAH }^{63} \\
\text { Benzylpenicilin } \\
\text { Glucuronide- } \\
\quad \text { conjugates }\end{array}$ & $\begin{array}{l}0.039 \\
0.043\end{array}$ & 0.8 & & $\begin{array}{r}168 \\
29\end{array}$ & $9.1^{64}$ & & Oat3 & $85^{55}$ \\
\hline $\begin{array}{l}\text { Naphtol } 17 \beta- \\
\text { glucuronide } 32\end{array}$ & 0.0231 & & & & & & & \\
\hline $\mathrm{E} 217 \beta \mathrm{G}^{37}$ & 0.037 & & & & & & $\begin{array}{l}\text { Oatp1a4 } \\
\text { Oatp1a5 } \\
\text { Oatp1c1 } \\
\text { Oat3 }\end{array}$ & $\begin{array}{c}3^{18}, 17^{37} \\
1.2^{50}, 40^{28} \\
10^{44} \\
8,4^{37}\end{array}$ \\
\hline \multicolumn{9}{|l|}{ Sulfate-conjugates } \\
\hline Estrone sulfate ${ }^{36}$ & 0.063 & 1.1 & 69.3 & 96 & & & $\begin{array}{l}\text { Oatp1a4 } \\
\text { Oatp1a5 } \\
\text { Oat3 }\end{array}$ & $\begin{array}{c}11^{18} \\
268^{28} \\
2^{50}, 5.3^{61}\end{array}$ \\
\hline DHEAS $^{35}$ & 0.0268 & 4.7 & 126 & 33 & 11.4 & & $\begin{array}{l}\text { Oatp1a4 } \\
\text { Oatp1a5 } \\
\text { Oat3 }\end{array}$ & $\begin{array}{c}17^{20} \\
162^{28} \\
12^{61}\end{array}$ \\
\hline $\begin{array}{l}\text { Indoxyl sulfate }{ }^{53} \\
\text { Peptides }\end{array}$ & 0.0108 & 0.95 & 10.3 & 298 & & & Oat3 & $158^{53}$ \\
\hline $\mathrm{RC}-160^{33}$ & 0.0546 & & & & & & & \\
\hline BQ-12334 & 0.00783 & & & 482 & & & $\begin{array}{l}\text { Oatp1a4 } \\
\text { Oatp1a5 }\end{array}$ & $\begin{array}{l}30^{20} \\
420^{28}\end{array}$ \\
\hline DPDPE $^{41}$ & & & & & $0.5(6)^{\dagger}$ & 24 & $\begin{array}{l}\text { Oatp1a4 } \\
\text { Oatp1a5 }\end{array}$ & $\begin{array}{c}19^{21} \\
140^{28}\end{array}$ \\
\hline $\begin{array}{l}\text { Thyroid hormone } \\
\text { (thyroxine) })^{45}\end{array}$ & & & & & 600 & 1 & Oatp1a4 & $6.5^{17}$ \\
\hline & & & & & & & $\begin{array}{l}\text { Oatp1a5 } \\
\text { Oatp1c1 }\end{array}$ & $\begin{array}{c}5^{17} \\
0.18{\text { (rat })^{44}} \\
0.34 \text { (mouse) }^{45}\end{array}$ \\
\hline
\end{tabular}

*Parameters were obtained from in vivo Km values corrected by a dilution factor. ${ }^{\dagger}$ The uptake clearance determined in P-gp knockout mice. DPDPE $=[$-penicillamine $(2,5)]$-enkephalin; GSH $=$ glutathione.

maining radioactivity in the brain after microinjection into the cerebral cortex (Table 2). In addition, the brain efflux index method has been employed to investigate the efflux transport across the BBB of taurocholate, estrone sulfate, dehydroepiandrosterone sulfate, and E217 $\beta$ G (Table 2), which was characterized by saturation, except $\mathrm{E} 217 \beta \mathrm{G}$ due to its low solubility in the buffer, and inhibition by simultaneously administered probenecid. ${ }^{34-37}$ Inhibition studies were carried out to investigate the contribution of transporters to the efflux transport of E217 $\beta$ G after microinjection (FIG. 2). ${ }^{37} \mathrm{Si}-$ multaneous injection of digoxin, a high affinity substrate of Oatp1a4, caused a $40 \%$ inhibition of the elimination of E217 $\beta \mathrm{G}$ from the brain, whereas probenecid and taurocholate inhibited the efflux of E217 $\beta \mathrm{G}$ almost com- pletely. The degree of inhibition by digoxin includes the contribution of Oatp1a4, and thus, Oatp1a4 account for the elimination partly. Because the effect of $p$-aminohippurate $(\mathrm{PAH})$, a typical substrate/inhibitor of Oat/OAT (see below), was minimal, but significant ( $\sim 20 \%$ inhibition), a PAH-sensitive efflux mechanism, presumably Oat3 described later, is involved in this efflux partly. Another unidentified taurocholate-sensitive transporter makes a relatively similar contribution to Oatp1a4 $(\sim 40 \%){ }^{37}$

Kitazawa et al. ${ }^{34}$ found that the efflux of taurocholate across the BBB after microinjection was inhibited by cyclic peptides such as BQ-123 and occtreotide as well as probenecid and cholate. Conversely, the efflux of BQ123 across the BBB was inhibited by taurocholate. $\mathrm{Mu}$ - 

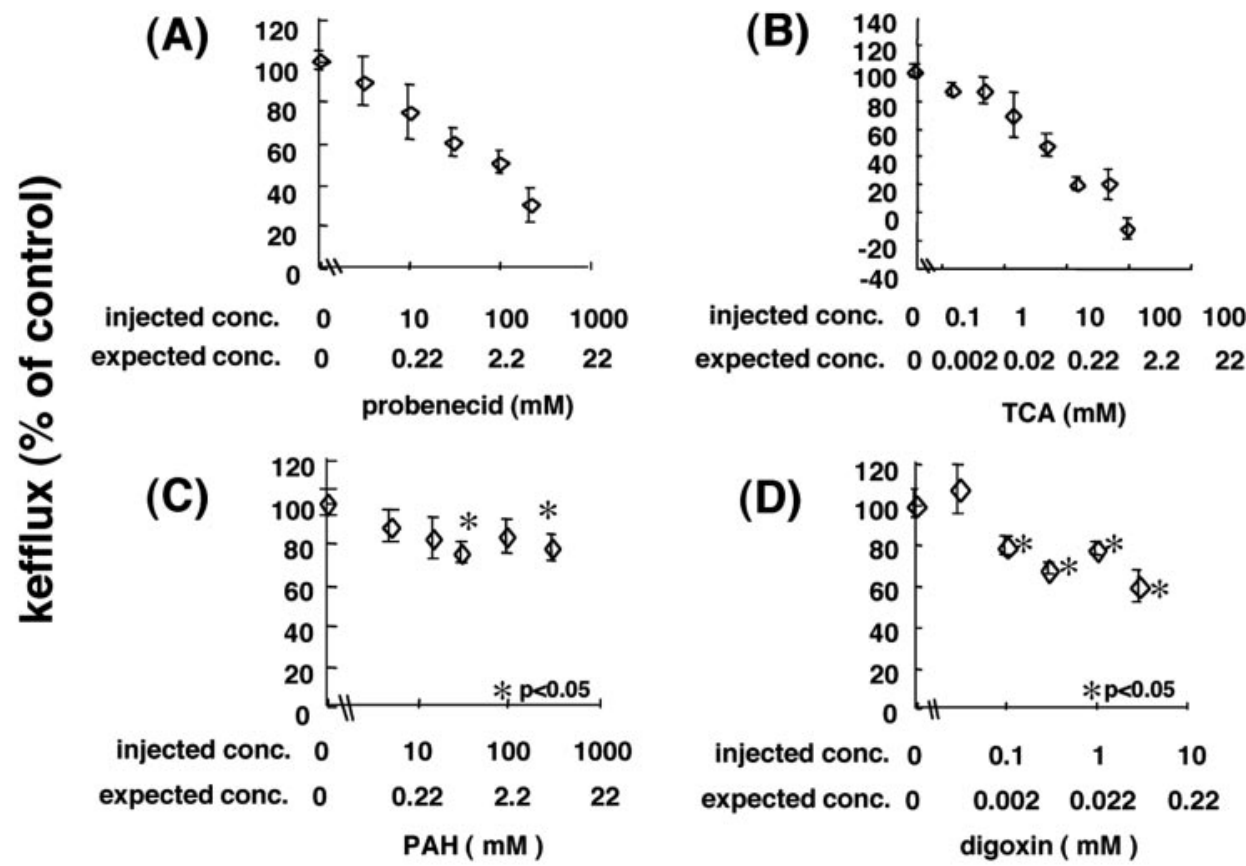

FIG. 2. Effect of probenecid, taurocholate, digoxin, and $p$-aminohippurate on the elimination of E217 $\beta G$ after intracerebral microinjection. E217 $\beta \mathrm{G}$ is eliminated from the brain at a rate constant of $0.037 \pm 0.001 \mathrm{~min}^{-1}$. Probenecid (A), taurocholate (B), $p$-aminohippurate $(C)$, and digoxin (D) were simultaneously microinjected into the cerebrum, and their effect on the elimination of E217 $\beta G$ from the cerebrum was examined. Each value of expected concentration is estimated by the concentration in the injectate divided by the dilution factor. Results are given as a ratio with respect to the elimination rate constant determined in the absence of unlabeled inhibitors. Each points represent mean \pm SEM $(n=3)$. *, Significant different from the control $(p<0.05)$. Reproduced with permission from Sugiyama et al. Characterization of the efflux transport of $17 \beta$-estradiol-D-17 $\beta$-glucuronide from the brain across the blood-brain barrier. $J$ Pharmacol Exp Ther 298:316-322. Copyright ${ }^{\odot}$ The American Society for Pharmacology and Experimental Therapeutics, 2001. All rights reserved. ${ }^{37}$

tual inhibition studies involving BQ-123 and taurocholate were carried out. Although the Michaelis constant $\left(\mathrm{K}_{\mathrm{m}}\right)$ and $\mathrm{IC}_{50}$ values of taurocholate were not greatly different $(0.4 v s 0.12 \mathrm{nmol} / 0.2 \mu \mathrm{l}$ injectate, respectively), the corresponding parameters of BQ-123 showed a marked difference $(2.9$ and $0.074 \mathrm{nmol} / 0.2 \mu \mathrm{l}$ injectate of BQ-123, respectively). ${ }^{34}$ Thus, it is possible that taurocholate and BQ-123 are eliminated from the brain by different transporters. Their in vivo $\mathrm{K}_{\mathrm{m}}$ values were roughly corrected by introducing a dilution factor to allow a comparison with the $\mathrm{K}_{\mathrm{m}}$ values for Oatp1a4 (65 and $30 \mu \mathrm{M}$, respectively). The in vivo $\mathrm{K}_{\mathrm{m}}$ value of taurocholate is within a range of the $\mathrm{K}_{\mathrm{m}}$ value of Oatp1a4 (Table 2). ${ }^{17,38}$ However, the in vivo $\mathrm{K}_{\mathrm{m}}$ value of BQ-123 is much greater than that of Oatp1a4, whereas the $\mathrm{IC}_{50}$ value of BQ-123 for the efflux of taurocholate across the BBB is similar (Table 2). Taking these findings into consideration, it is likely that the efflux across the BBB is mediated by other transporter, although BQ-123 is a substrate of Oatp1a4.

Sulfoconjugates of steroids, such as estrone sulfate and dehydroepiandrosterone sulfate (DHEAS), undergo efflux across the BBB in intact form. ${ }^{35,36}$ Especially, DHEAS is a so-called neurosteroid, which is synthesized from cholesterol locally in the neuron, and modulates neurotransmission, ${ }^{39,40}$ and the efflux system for
DHEAS has been considered to be one of inactivation mechanism. ${ }^{35}$ The efflux clearance of DHEAS, estimated from the elimination rate constant and the uptake by brain slices, was markedly greater than the in vivo uptake clearance determined using the in situ brain perfusion technique (125 vs $11 \mu \mathrm{l} / \mathrm{min} \cdot \mathrm{g}$ brain) (Table 2). ${ }^{35}$ The efflux of DHEAS was saturable with an in vivo $\mathrm{K}_{\mathrm{m}}$ value similar to that of Oatp1a4 (Table 2) and was inhibited by probenecid, bile acids (taurocholate and cholate), and other sulfo-steroids (estrone sulfate and estradiol sulfate), whereas PAH had no effect. Estrone sulfate is another sulfate-conjugate whose efflux across the BBB was examined. Estrone sulfate also undergoes efflux across the BBB by a saturable mechanism and is inhibited by probenecid, bile acids, and DHEAS. ${ }^{36}$ However, the in vivo $\mathrm{K}_{\mathrm{m}}$ value of estrone sulfate was nine-fold greater than that for Oatp1a4 (Table 2), and thus, it is possible that the transporter responsible for the efflux transport of estrone sulfate is different from that of DHEAS.

In addition to efflux across the BBB, the luminal localization of Oatp1a4 at the BBB suggests its involvement in the uptake process. Dagenais et al. ${ }^{41}$ demonstrated that the brain uptake of [D-penicillamine-2,5]enkephalin was greater in Mdr1a-Pgp knockout mice (FIG. 3). The increased brain uptake in Mdr1a-P-gp 
A

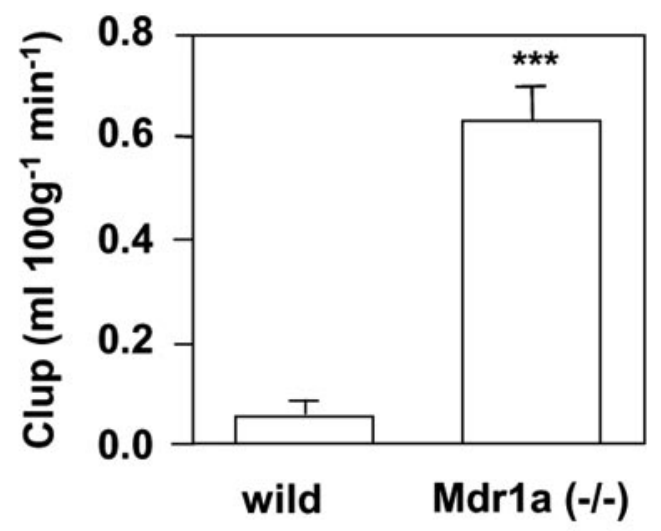

B

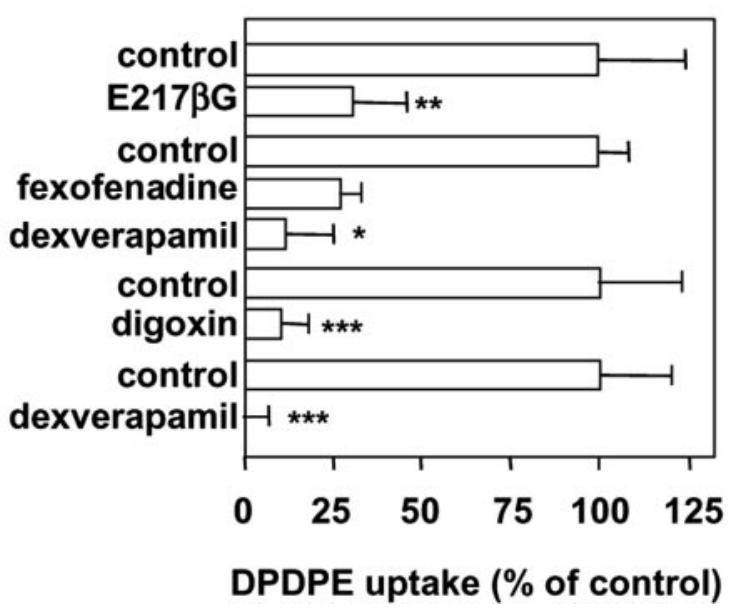

FIG. 3. Limitation of Oatp1a4-mediated uptake of [D-penicillamine-2,5]-enkephalin by P-gp at the BBB. A: The initial uptake clearance of [D-penicillamine-2,5]-enkephalin in the right cerebral hemisphere was determined in wild-type and Mdr1a P-gp knockout mice after $180 \mathrm{~s}$ of perfusion. Data are presented as mean $\pm \operatorname{SD}(n=4)$. ${ }^{\star \star *}, p<0.001$. B: The effect of inhibitors was examined for the brain uptake of [D-penicillamine-2,5]-enkephalin in Mdr1a P-gp knockout mice after $120 \mathrm{~s}$ of perfusion. The concentration used in this experiment is as follows: E217 $\beta$ G, 200 $\mu \mathrm{M}$; fexofenadine, $150 \mu \mathrm{M}$; dexverapamil, $300 \mu \mathrm{M}$; digoxin $25 \mu \mathrm{M}$. Data are presented as mean $\pm \operatorname{SD}(n=4)$. ${ }^{\star \star \star}, p<0.001$; ${ }^{\star \star}$, $p<0.01$; and ${ }^{*}, p<0.05$. Reproduced with permission from Dagenais et al. Uptake and efflux of the peptidic $\delta$-opioid receptor agonist. Neurosci Lett 301:155-158. Copyright ๑ 2001, Elsevier. All rights reserved. ${ }^{41}$

knockout mice was saturable with a $\mathrm{K}_{\mathrm{m}}$ value of $24 \mu \mathrm{M}$, which is comparable with that of Oatpla4 $\left(19 \mu \mathrm{m}^{21}\right)$, and the involvement of Oatpla4 was supported by inhibition by Oatp1a4 substrates E217 $\beta$ G and digoxin (FIG. 3). Thus, it is likely that Oatp1a4 accounts for the luminal uptake of [D-penicillamine2,5]-enkephalin, although it undergoes active efflux by P-gp at the BBB and shows limited brain distribution. The brain uptake of another Oatpla4 substrate, taurocholate, determined by the in situ brain perfusion method in rats did not show any significant uptake during the infusion period although the initial distribution volume was greater than that of inulin. ${ }^{34}$ It may be possible that luminal efflux mechanism may limit the brain uptake of taurocholate at the BBB as in the case of [D-penicillamine2,5]-enkephalin, and knockout of the efflux transporter makes it possible to detect Oatp1a4-mediate uptake of taurocholate.

As in vitro model of the BBB, Hosoya et al..$^{42}$ have developed a conditionally immortalized cell line from a transgenic rat harboring the temperature-sensitive simian virus 40 large $\mathrm{T}$-antigen. These cell lines express active large $\mathrm{T}$-antigen and grow well at $33^{\circ} \mathrm{C}$. They also grow at $37^{\circ} \mathrm{C}$ but not at $39^{\circ} \mathrm{C}$; however their growth is restored when the temperature of the culture was lowered to $33^{\circ} \mathrm{C}$. RT-PCR analysis showed that Oatp1a4 and Oatp1a5 are expressed in the cell line, at least at an mRNA level. ${ }^{27,35}$ Significant uptake of DHEAS and digoxin was detected in TM-BBB4. The uptake of DHEAS by TM-BBB4 was saturable with a $K_{m}$ value similar to that for Oatp1a4, and inhibited by amphipathic organic anions and digoxin, but not by $\mathrm{PAH}^{35}$ Therefore, it is likely that Oatpla4 function is maintained in the cell line.

\section{The molecular characteristics of Oatp1c1}

Oatp1c1 was originally referred to as BBB-specific anion transporter 1 (BSAT1), which was isolated using gene microarray techniques by comparing the gene-expression profile of cDNA from the brain capillaries with that from the liver and kidney. ${ }^{43}$ Oatp1c1 cDNA consists of 2148 bp that encode a 716-amino acid residue protein with 12 putative membrane-spanning domains. Oatp1c1 shows relatively low homology to Oatp1a4 (46\% identity in amino acid levels). Northern blot analysis revealed its predominant expression in the brain, ${ }^{43,44}$ and Oatp1c1protein $(90 \mathrm{kDa})$ was enriched in the brain capillary enriched fraction compared with brain homogenate. ${ }^{44}$ Furthermore, immunohistochemical staining has demonstrated that Oatp1c1 is localized both on the luminal and abluminal membrane of the rat/mouse brain capillaries, ${ }^{44}$ and the basolateral membrane of mouse choroid plexus. ${ }^{45}$ Functional characterization using HEK293 cell expressing Oatp1c1 revealed that the substrates include organic anions, such as E217 $\beta \mathrm{G}$, cerivastatin and troglitazone sulfate, thyroxine, and its inactive metabolite $\left[3,3^{\prime}, 5^{\prime}\right.$ triiodothyronine (reverse T3) $] .^{44}$ Among these substrates, thyroxine and reverse $\mathrm{T} 3$ show the highest transport activity. ${ }^{44}$

Because the expression of Oatp1c1 has been reported to be regulated by plasma thyroid condition, it is suggested that Oatp1c1 plays an important role in the thyroxine transport at the BBB. Tohyama et al. ${ }^{45}$ investigated the uptake mechanism of thyroxine by the brain using the in situ brain perfusion technique in mice, and found that thyroxine uptake by the brain is saturable. According to in vitro inhibition study using cDNA transfectant, taurocholate, estrone sulfate, and probenecid are inhibitors for Oatp1c1, but digoxin, PAH or benzylpenicillin are not. Thyroxin uptake by the brain was inhib- 
ited by taurocholate completely, but estrone sulfate has partial effect. Therefore, Oatp1c1 accounts for the thyroxine uptake partly. Because digoxin and neutral amino acids had no effect, the contribution of Oatp1a4 and neutral amino acid transporter is minimal or none. OATP1C1 (SLCO1C1, OATP1C1), the human ortholog of Oatp1c1, is expressed in the brain where it is widely expressed except in the cerebellum, and in the testis where it is expressed in the Leydig cells. ${ }^{46}$ Thyroxine and reverse $\mathrm{T} 3$ are substrates exhibiting high transport activities by OATP1C1 as well. ${ }^{46}$ Whether OATP1C1 shows the same membrane localization at the BBB and choroid plexus remains to be elucidated.

\section{SLC22}

The SLC22 family includes organic cation transporters (Oct/OCT, SLC22Al 3), organic cation/carnitine transporters (Octn/OCTN, SLC22A4, -5) organic anion transporters (Oat/OAT, SLC22A6 8, $-10,-11$ ), and their related transporters such as URAT1/renal specific transporter (RST) (SLC22A12) and CT2 (SLC22A16). CT2 and URAT1/RST are transporters of carnitine and urate, respectively. ${ }^{47,48}$ Among the members of the SLC22, OAT3, OCTN2, and RST have been shown to be expressed in the BBB (Table 1). This section focuses on the molecular characteristics of OAT3, OCTN2, RST, and briefly Oct/OCT family. Review articles about the Oat/ OAT family are available. ${ }^{49}$

\section{The molecular characteristics of Oat3/OAT3}

Oat3 (Slc22a8) was cloned from rat brain cDNA library as homolog of organic anion transporter $1 .^{50}$ The cDNA consists of 536 amino acids with an apparent molecular mass of $92 \mathrm{kDa}$, and hydropathy plot analysis predicted 12 putative transmembrane domains. Oat3 shows the highest expression in the liver, and to lesser extent in the kidney, brain, and eye ${ }^{50}$ RT-PCR analysis using primers designed for three rat Oat mRNAs revealed the expression of Oat 3 in the brain capillary enriched fraction, but the mRNA expression of other Oat isoforms, such as Oat1 and Oat2, was below the limit of detection. ${ }^{51}$ Western blot analysis revealed the protein expression of Oat 3 in the brain capillary enriched fraction with greater molecular mass than in the kidney. ${ }^{51,52}$ Because the molecular mass is similar in the brain capillary and kidney after peptide $N$-glycarase F treatment, the difference in the apparent molecular mass is ascribed to the difference in glycosylation. ${ }^{51}$ Immunochemical staining revealed abluminal localization of Oat 3 in the brain capillaries, ${ }^{51-54}$ however, faint signals were also reported on the luminal membrane of rat brain capillaries. ${ }^{51}$ In addition, mRNA expression of Oat3 was detected in a immortalized rat BCEC (TR-BBB), although its protein expression remains unknown. ${ }^{53}$ rOat3 is also expressed in brush border membrane of the choroid plexus, ${ }^{55}$ whereas both OAT1 and OAT3 have been shown to be expressed in the human choroid plexus by immunohistochemical staining, although their membrane localization remains to be clarified. ${ }^{56}$

Functional expression in X. laevis oocytes and mammalian cells has revealed that Oat 3 has a broad substrate specificity including amphipathic organic anions, such as $\mathrm{E} 217 \beta \mathrm{G}$, estrone sulfate, and dehydroepiandrosterone sulfate, hydrophilic organic anions, such as PAH and benzylpenicillin, and the organic cations, cimetidine and ranitidine. ${ }^{50,55,57}$ Estrone sulfate uptake and efflux via Oat 3 are not trans-stimulated by ochratoxin A, PAH, or estrone sulfate in Oat3-cRNA injected X. oocytes, ${ }^{50}$ whereas Sweet et al. ${ }^{58}$ demonstrated that estrone sulfate and PAH uptake by Oat3-expressing oocytes was stimulated by an outward concentration gradient of glutarate formed by coexpression of the sodium-dicarboxylate cotransporter (NaDC-1). The efflux of glutarate from inside the cells was greater in OAT3-expressing oocytes than in control oocytes and was stimulated by extracellular OAT3 substrates, such as $\alpha$-ketoglutarate, glutarate, $\mathrm{PAH}$, cimetidine, and urate. Therefore, it is likely that Oat3/OAT3 is an exchanger and an outward concentration gradient of dicarboxylates, such as $\alpha$-ketoglutarate, formed by the $\mathrm{NaDC}$ and the tricarboxylate cycle, may drive Oat $3 /$ OAT3-mediated transport.

The Oat3 knockout mouse was established by Sweet et al., ${ }^{59}$ and this allows more direct insight into its role in the kidney and CP. This mouse strain is healthy and exhibits no significant physiological abnormalities compared with the corresponding wild-type mouse. Most of the uptake of amphipathic organic anions, such as taurocholate and estrone sulfate, is markedly reduced in kidney slices from the Oat 3 knockout mouse compared with that from the wild-type mouse. ${ }^{59}$ In addition, the accumulation of fluorescein is markedly reduced in the isolated CP from the Oat3-knockout mouse. In contrast, knockout of Oat3 gene did not affect the uptake of fluorescence-labeled methotrexate by isolated brain capillaries; however, the effect of knockout of Oat 3 on the efflux transport of other Oat 3 substrates remains to be elucidated. The microinjection technique that introduces test compounds into the cerebral cortex has been carried out in mice. ${ }^{33,60}$ Comparing the elimination curve in wild-type and Oat 3 knockout animals will reveal any involvement of Oat3 in efflux across the BBB.

\section{The efflux transport of Oat3/OAT3 substrates across the BBB}

It has been suggested that Oat 3 plays a major role in the efflux transport of other Oat 3 substrates, such as $\mathrm{PAH}$, benzylpenicillin, indoxylsulfate, and homovanillic acid, ${ }^{51-53}$ but only a limited role in the efflux transport of amphipathic organic anions such as estradiol 17 $\beta$-gluco- 
ronide (E217 $\beta \mathrm{G})$, DHEAS, and estrone sulfate, although it plays major role in the renal uptake of these amphipathic organic anions. ${ }^{59,61,62}$

PAH was found to be eliminated in a saturable manner from the cerebral cortex after microinjection. ${ }^{63}$ The efflux clearance of PAH across the BBB $(47 \mu \mathrm{l} / \mathrm{min} / \mathrm{g}$ brain) was estimated by multiplying the elimination rate constant $\left(0.059 \mathrm{~min}^{-1}\right)$ and the steady state uptake by brain slices $(0.8 \mathrm{ml} / \mathrm{g}$ brain). The uptake clearance of $\mathrm{PAH}$ across the BBB was evaluated by the in vivo carotid artery injection technique and found to be below the uptake clearance of inulin (12 vs $17 \mu \mathrm{l} / \mathrm{min} / \mathrm{g}$ brain, respectively) (Table 2). Thus, the efflux clearance of PAH across the BBB is greater than the uptake clearance. The efflux was saturable with a $\mathrm{K}_{\mathrm{m}}$ value, corrected by a dilution factor, very close to its $\mathrm{K}_{\mathrm{m}}$ value by the isolated rat choroid plexus (396 vs $354 \mu \mathrm{M}$ ) in which PAH uptake is suggested to be by Oat3 (Table 2); this is based on a comparison of kinetic parameters including the Ki values of inhibitors of the uptake by the isolated choroid plexus and Oat $3 .^{55}$

Benzylpenicillin is eliminated from the brain with similar elimination rate constant to that of PAH via a saturable mechanism. ${ }^{51}$ Mutual inhibition studies were carried out to examine whether the efflux of PAH across the BBB shares the same transporter as benzylpenicillin. ${ }^{51}$ The $K_{m}$ value of PAH was comparable with its $K_{i}$ for the efflux transport of benzylpenicillin, and vice versa. In addition, cimetidine and pravastatin, inhibitors of Oat3, significantly inhibited the efflux both of PAH and benzylpenicillin to a similar degree. Thus, this suggests that $\mathrm{PAH}$ and benzylpenicillin efflux is mediated by the same transporter at the BBB. The uptake of benzylpenicillin by the brain was evaluated in rat using the in situ brain perfusion technique ( $9 \mu \mathrm{l} / \mathrm{min} / \mathrm{g}$ brain), and found to be a saturable mechanism accounting for most of the uptake. ${ }^{64}$ If the distribution volume of benzylpenicillin in the brain is assumed to be similar to that of PAH, the efflux clearance across the BBB will be greater than the uptake clearance.

$\mathrm{PAH}$, benzylpenicillin, and cimetidine significantly inhibit the efflux transport of homovanillic acid and indoxylsulfate across the BBB after microinjection into the cerebral cortex, and it is likely that the efflux transport of these compounds is mediated by the same transporter of PAH and benzylpenicillin, presumably Oat3. Homovanillic acid is one of the metabolites of dopamine. In the $X$. laevis oocyte expression system, the metabolites of dopamine and serotonin have been suggested to be substrates of Oat 3 because they inhibit the uptake of estrone sulfate by rOat $3 .{ }^{50}$ Oat 3 may be involved in the elimination of these inactivated metabolites from the brain.

\section{The molecular characteristics of RST}

RST was originally isolated from mouse kidney using the signal sequence trap method without any functional report $^{65}$ and is a mouse homolog of human urate transporter (URAT1) (74\% identity at an amino acid level). Although Northern blot analysis demonstrated its predominant expression in the kidney, RT-PCR and Western blot analyses detected its expression in the brain capillary-enriched fraction and choroid plexus. ${ }^{66}$ Thus, it is likely that the expression of RST is restricted to the brain capillaries and choroid plexus where its membrane localization remains to be elucidated. mRST-mediated uptake of organic anions was increased by substituting $\mathrm{K}^{+}$for $\mathrm{Na}^{+}$or by oubain- and $\mathrm{Ba}^{2+}$ treatments. ${ }^{66} \mathrm{Be}-$ cause these treatments cause a depolarization of membrane voltage, RST has been hypothesized to be a facilitative transporter. Furthermore, introduction of RST cDNA to the LLC-PK1, an epithelial cell line from percine kidney, expressing Oat 3 at the basal membrane increased the basal-to-apical transport of benzylpenicillin and urate (FIG. 4), ${ }^{66}$ suggesting that it can mediate the efflux. In the BBB and BCSFB, RST may be involved in the efflux transport of organic anions across the BBB and BCSFB by coordination of Oat3. Using confocal microscopy, Breen ${ }^{67}$ suggested that the excretion of fluorescein across the basolateral membrane of choroid plexus epithelial cells is membrane-voltage dependent. It is possible that RST accounts for this excretion in the choroid plexus, and coordination of Oat 3 and RST allows vectorial transport across the BBB and BCSFB.

\section{The molecular characteristics of the Octn/OCTN family}

Three isoforms (Octn1 Octn3, Slc22a4, -5) have been characterized in rodents, whereas two isoforms (OCTN1 and OCTN2) have been characterized in humans. The Octn/OCTN family has been reviewed recently. ${ }^{49}$

Octn2 expression has been detected in primary cultured rat BCEC as well as whole brain. ${ }^{68}$ Octn2/OCTN2 has been characterized as a sodium-dependent carnitine transporter, ${ }^{69,70}$ although it also transports tetaraethylammonium (TEA) with lower transport activity compared with that of carnitine. ${ }^{71}$ Octn2 is hereditarily deficient in the juvenile visceral steatosis (jvs) mouse, ${ }^{72}$ an animal model of primary systemic carnitine deficiency (OMIM 212140) caused by a single nucleotide mutation of Octn2 gene. ${ }^{72}$ The functional involvement of Octn 2 in the brain uptake of carnitine was investigated in normal and $j v s$ mouse, ${ }^{68,73,74}$ and it was found that functional loss of Octn2 is associated with decreased brain concentration of acetyl-carnitine. ${ }^{73}$ Therefore, luminal localization at the BBB has been suggested, although its membrane localization in the brain capillaries has not been determined. Octn2 has been suggested to be involved in the renal elimination of organic cations because the renal 

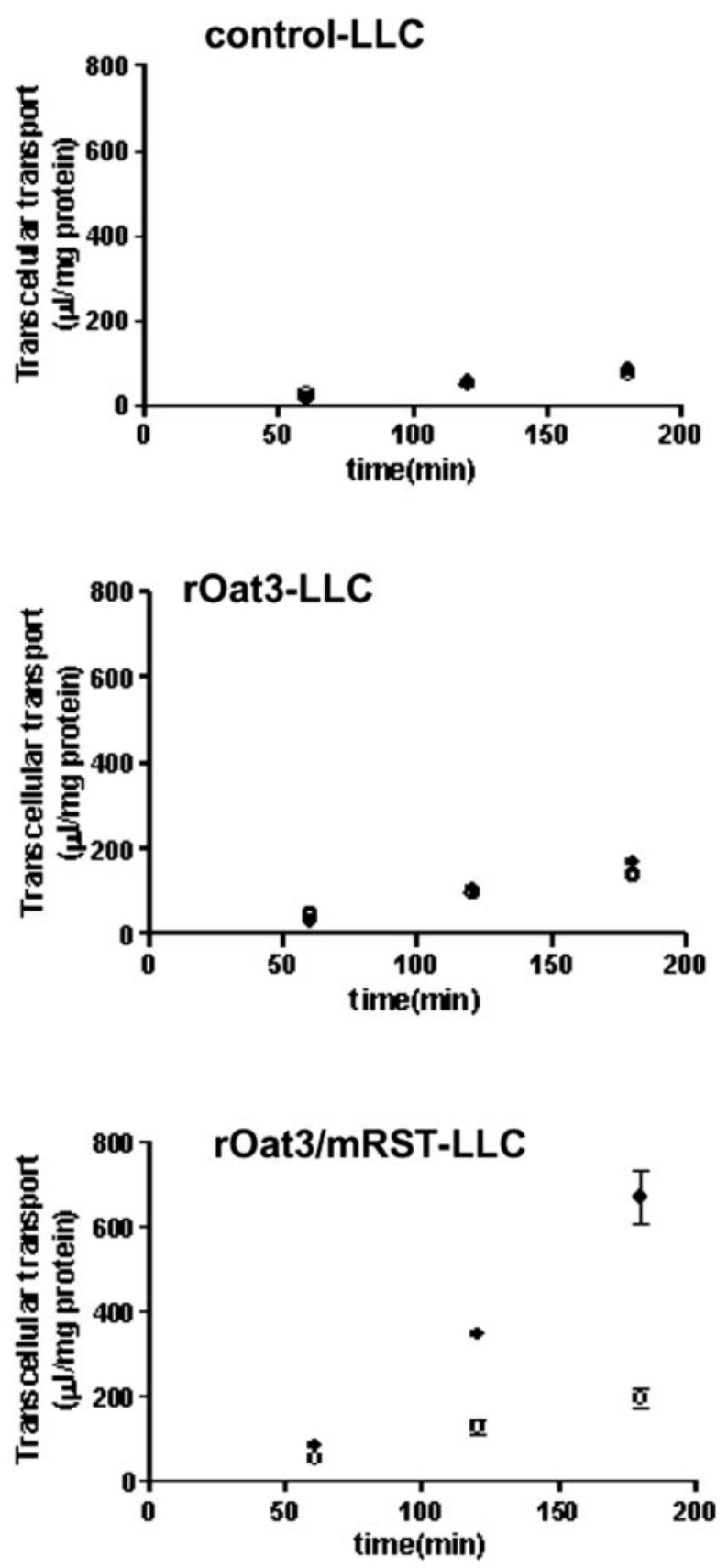

FIG. 4. Vectorial transport of benzylpenicillin in the double transfectant of rat Oat3 and mouse RST in LLC-PK1. Transcellular transport of benzylpenicillin $(0.5 \mu \mathrm{M})$ across LLC-PK1 monolayers expressing rOat3 and both rOat3 and mRST (rOat3/ mRST: double transfectant) was compared with that across the control LLC-PK1 monolayer. Open and closed circles represent the transcellular transport in the apical-to-basal and basal-to-apical directions, respectively. Each point represents the mean \pm SEM ( $n$ $=3$ ). Reproduced with permission from Imaoka et al. The renalspecific transporter mediates facilitative transport of organic anions at the brush border membrane of mouse renal tubules. J Am Soc Nephrol 15:2012-2022. Copyright $\odot$ 2004, Lippincott Williams \& Wilkins. All rights reserved. ${ }^{6}$

clearance of TEA was significantly decreased in $j v s$ mouse compared with that in normal mice. ${ }^{75}$ Luminal localization of Octn2 may play a role in the efflux of organic cations in an exchange of plasma carnitine and/or acethyl-carnitine because carnitine and TEA exhibit mutual trans-stimulation. ${ }^{75}$

\section{The molecular characteristics of the Oct/OCT family}

The OCT-mediated uptake is facilitative transport characterized by its membrane voltage dependence, and the isoforms of the Oct/OCT family show broad substrate specificity to small and hydrophilic organic cations, such as TEA and $\mathrm{N}$-methylnicotineamide. ${ }^{49,76}$ The expression of the Oct/OCT isoforms at the BBB remains unknown, whereas they are expressed in the choroid plexus, although the isoform expressed in the choroid plexus is controversial. RT-PCR analysis by Sweet et al. ${ }^{77}$ detected the expression of Oct2 (Slc22a2) and Oct3 (Slc22a3) mRNA, but not Oct1 (Slc22al) mRNA; however, mRNA quantification by Choudhuri et al. ${ }^{78}$ revealed low-level expression of Oct1 and Oct 3 in the rat $\mathrm{CP}$, and the expression level of Oct 2 mRNA was below the limit of detection. Oct1-, Oct2-, and Oct3-, as well as Oct1/Oct2 double knockout mice, have been developed, and these will be a useful animal model for examining the involvement of Oct1, Oct2, and Oct3 in the efflux transport of organic cations across the BBB. ${ }^{79-81}$

Overlapped substrate specificity between the members of SLC families and ABC transporters

$\mathrm{ABC}$ transporters have been characterized by one or two cytoplasmically located nucleotide binding domains acting as a catalytic domain for nucleotide hydrolysis. Some ABC transporters, which show broad substrate specificity, have been identified on the luminal membrane of the BCEC including P-glycoprotein, multidrug resistance-associated protein (MRP) $-1,-2,-4$, and -5 (ABCC1/ABCC2/ABCC4/ABCC5), ${ }^{60,82,83,83 a}$ and breast cancer resistant protein (BCRP/ABCG2). ${ }^{84-86}$ The molecular characteristics of these $\mathrm{ABC}$ transporters have been reviewed. ${ }^{87-90}$ This section focuses on the overlap of substrate specificity between Oatps/Oats and $\mathrm{ABC}$ transporters.

There is coordination of the members of SLC family and $\mathrm{ABC}$ transporters in the hepatobiliary transport, ${ }^{12,90,91}$ and the renal secretion ${ }^{92,93}$ of organic anions. Sasaki et al. ${ }^{94}$ and Cui et al ${ }^{95}$ clearly demonstrated this coordination in vitro by introducing both OATP1B1/ OATP1B3 and MRP2 to a polarized cell line (MDCK-II cells), and Mita et al. ${ }^{96}$ have succeeded in establishing at cell line expressing Ntcp and Bsep in LLC-PK1 cells for hepatobiliary transport of bile acids.

Studies involving the BBB have shown that such coordination of $A B C$ and SLC transporters also occurs in the BBB. As described previously, it has been suggested that the luminal uptake of [D-penicillamine-2,5]-enkephalin is accounted for by Oatp1a4, and it also undergoes efflux by P-gp at the BBB resulting a small brain uptake (FIG. 3). ${ }^{41}$ In addition, fexofenadine, antihista- 
TABLE 3. Substrates of ABC Transporters Expressed in the BBB

\begin{tabular}{|c|c|c|}
\hline ABC Transporters & Localization & Substrates \\
\hline $\mathrm{P}-\mathrm{gp} / A B C B 4$ & Luminal & $\begin{array}{l}\text { Lipophilic neutral and cationic compounds E217 } \beta \mathrm{G} \text {, methotrexate, fexofenadine, } \\
\text { DPDPE }\end{array}$ \\
\hline MRP1/ABCCl & Luminal & glutathione- and glucuronide-conjugates estrone sulfate (+GSH) \\
\hline MRP2/ABCC2 & Luminal & $\begin{array}{l}\text { Glutathione- and glucuronide-conjugates non conjugated amphipathic organic anions } \\
\text { cyclic peptide (BQ-123) }\end{array}$ \\
\hline MRP4/ABCC4 & Luminal/abluminal & $\begin{array}{l}\text { Steroids conjugated with sulfate and glucuronide (DHEAS and E217 } \beta G \text { ) prosta- } \\
\text { glandins, methotrexate, and folate nucleotides and nucleoside analogus (adfovir } \\
\text { and 6-mercaptopurine) }\end{array}$ \\
\hline MRP5/ABCC5 & Luminal & cAMP, cGMP \\
\hline $\mathrm{BCRP} / A B C G 2$ & Luminal & $\begin{array}{l}\text { Anticancer drugs (doxorubicin, mitoxantrone, topotecan and SN-38) glucuronide } \\
\text { conjugates (E217 } \beta \mathrm{G}, 4 \text {-methylumbelliferone glucuronide and E3040 glucuronide) } \\
\text { sulfate conjugates (estrone sulfate, estradiol sulfate, DHEAS, 4-methylumbellifer- } \\
\text { one sulfate, and E3040 sulfate) }\end{array}$ \\
\hline
\end{tabular}

$\mathrm{GSH}=$ glutathione

mine drug, is a substrate of P-gp and Oatp $1 \mathrm{a} 4,{ }^{97}$ and its brain uptake is increased in Mdr1a P-gp knockout mice. ${ }^{97}$ It is possible that the luminal uptake of fexofenadine is mediated by Oatp1a4. In addition to P-gp, Sugiyama et al. ${ }^{60}$ have suggested an involvement of Mrp1 in the luminal efflux of amphipathic organic anions by comparing the concentration time profile of E217 $\beta \mathrm{G}$ after microinjection into the cerebral cortex between wild-type and Mrp1 knockout mice. It has been suggested that the uptake process at the abluminal membrane is accounted for by multiple transporters as described in the previous section, and thus, a coordination of uptake transporters and Mrp1 will account for the vectorial transport from the brain-to- blood side, at least partially together with P-gp. Mrp1 substrates include glucuronide and glutathione-conjugates, and estrone sulfate in the presence of glutathione, which are shared by the members of the SLCO/SLC21A and SLC22A families.

For other $\mathrm{ABC}$ transporters, there is no in vivo evidence supporting their involvement in efflux transport across the BBB (see Note Added in Proof), although there is conflicting evidence for the expression of Mrp2 in the BBB. ${ }^{60,82}$ The substrate specificity of MRP2, MRP4, MRP5, and BCRP is summarized in Table 3. Because the substrate specificities show an overlap, they could be involved in the efflux transport at the luminal membrane of the BBB. Knockout animals have been established for Bcrp ${ }^{98}$ and Mrp4 $4{ }^{99}$ which will allow us to investigate their contribution to the total efflux process.

\section{CONCLUDING REMARKS}

This review has summarized the recent progress in understanding the efflux transport systems at the BBB. Multiple transporters have been identified on the brain capillaries, and operate as detoxification system in the brain for a variety of natural and synthetic organic chem- icals. They prevent drugs designed to treat CNS diseases from achieving clinically significant concentration in the brain. Overcoming the efflux systems at the BBB is one of the important topics for future research. Transporters on the luminal membrane, such as Oatp1a4 and Oatp1c1, may be available to deliver drugs to the CNS, and as in the case of [D-penicillamine-2,5]-enkephalin, and other P-gp substrates, overcoming efflux transporters at the luminal membrane will improve the pharmacological effect. Adachi et al. ${ }^{100}$ have shown a correlation between transepithelial transport across a monolayer of LLC-PK1 expressing P-gp, and the ratio of the brain concentration between wild-type and Mdr1a P-gp knockout mice, which will allow us to quantitatively evaluate the contribution of efflux transporter at the BBB using in vitro studies. Such and in vitro system, including transfectants, will be very useful for other MRPs and BCRP as well as examining in vitro/in vivo correlations.

Interindividual difference in the efflux transport activity at the BBB due to genetic polymorphisms may give us a clue to understanding interindividual difference in drug response in addition to the interindividual difference in pharmacokinetics. Hoffmeyer et al. ${ }^{101}$ demonstrated that there is a genetic polymorphism associated with P-gp expression in the intestine, and subsequent reports have demonstrated that this is true in other organs ${ }^{102}$. Whether it affects P-gp expression in the BBB remains to be elucidated, but it may be that such a genetic polymorphism may account for the interindividual difference in P-gp function at the BBB leading to interindividual difference in drug response. Whether genetic polymorphisms are associated with the function of transporters remains to be elucidated.

Acknowledgments: This work was supported by grants-inaid from the Ministry of Education, Culture, Sports, Science and Technology of Japan. 
Note added in proof: During preparation of this article, Mrp4 was shown to be involved in the active efflux at the BBB using Mrp4 knockout mice in which the elimination of topotecan from the brain has been significantly delayed. ${ }^{83 a}$

\section{REFERENCES}

1. Pardridge WM. Introduction to the blood-brain barrier. Cambridge University Press, 1998.

2. Begley DJ, Brightman MW. Structural and functional aspects of the blood-brain barrier. Prog Drug Res 61:39-78, 2003.

3. Bazzoni G, Dejana E. Endothelial cell-to-cell junctions: molecular organization and role in vascular homeostasis. Physiol Rev 84:869-901, 2004.

4. Nitta T, Hata M, Gotoh S, Seo Y, Sasaki H, Hashimoto N, et al. Size-selective loosening of the blood-brain barrier in claudin-5deficient mice. J Cell Biol 161:653-660, 2003.

5. Segal MB. The choroid plexuses and the barriers between the blood and the cerebrospinal fluid. Cell Mol Neurobiol 20:183196, 2000.

6. Lee G, Dallas S, Hong M, Bendayan R. Drug transporters in the central nervous system: brain barriers and brain parenchyma considerations. Pharmacol Rev 53:569-596, 2001.

7. Kusuhara H, Sugiyama Y. Efflux transport systems for drugs at the blood-brain barrier and blood-cerebrospinal fluid barrier (Part 1). Drug Discov Today 6:150-156, 2001.

8. Sun H, Dai H, Shaik N, Elmquist WF. Drug efflux transporters in the CNS. Adv Drug Deliv Rev 55:83-105, 2003.

9. Begley DJ. ABC transporters and the blood-brain barrier. Curr Pharm Des 10:1295-1312, 2004

10. Lin JH. How significant is the role of P-glycoprotein in drug absorption and brain uptake? Drugs Today (Barc) 40:5-22, 2004

11. Schinkel AH. P-Glycoprotein, a gatekeeper in the blood-brain barrier. Adv Drug Deliv Rev 36:179-194, 1999

12. Mizuno N, Niwa T, Yotsumoto Y, Sugiyama Y. Impact of drug transporter studies on drug discovery and development. Pharmacol Rev 55:425-461, 2003.

13. Sakata A, Tamai I, Kawazu K, Deguchi Y, Ohnishi T, Saheki A, et al. In vivo evidence for ATP-dependent and P-glycoproteinmediated transport of cyclosporin A at the blood-brain barrier. Biochem Pharmacol 48:1989-1992, 1994.

14. Ohnishi T, Tamai I, Sakanaka K, Sakata A, Yamashima T, Yamashita $\mathrm{J}$, et al. In vivo and in vitro evidence for ATP-dependency of P-glycoprotein-mediated efflux of doxorubicin at the blood-brain barrier. Biochem Pharmacol 49:1541-1544, 1995.

15. Hagenbuch B, Meier PJ. The superfamily of organic anion transporting polypeptides. Biochim Biophys Acta 1609:1-18, 2003.

16. Hagenbuch B, Meier PJ. Organic anion transporting polypeptides of the OATP/ SLC21 family: phylogenetic classification as OATP/ SLCO superfamily, new nomenclature and molecular/ functional properties. Pflugers Arch 447:653-665, 2004.

17. Abe T, Kakyo M, Sakagami H, Tokui T, Nishio T, Tanemoto M, et al. Molecular characterization and tissue distribution of a new organic anion transporter subtype (oatp3) that transports thyroid hormones and taurocholate and comparison with oatp2. J Biol Chem 273:22395-22401, 1998.

18. Noe B, Hagenbuch B, Stieger B, Meier PJ. Isolation of a multispecific organic anion and cardiac glycoside transporter from rat brain. Proc Natl Acad Sci USA 94:10346-10350, 1997.

19. Gao B, Stieger B, Noe B, Fritschy JM, Meier PJ. Localization of the organic anion transporting polypeptide 2 (Oatp2) in capillary endothelium and choroid plexus epithelium of rat brain. J Histochem Cytochem 47:1255-1264, 1999.

20. Reichel C, Gao B, Van Montfoort J, Cattori V, Rahner C, Hagenbuch $\mathrm{B}$, et al. Localization and function of the organic aniontransporting polypeptide Oatp2 in rat liver. Gastroenterology 117:688-695, 1999.

21. Gao B, Hagenbuch B, Kullak-Ublick GA, Benke D, Aguzzi A, Meier PJ. Organic anion-transporting polypeptides mediate transport of opioid peptides across blood-brain barrier. J Pharmacol Exp Ther 294:73-79, 2000.

22. van Montfoort JE, Hagenbuch B, Fattinger KE, Muller M, Groothuis GM, Meijer DK, et al. Polyspecific organic anion transporting polypeptides mediate hepatic uptake of amphipathic type II organic cations. J Pharmacol Exp Ther 291:147-152, 1999.

23. Li L, Meier PJ, Ballatori N. Oatp2 mediates bidirectional organic solute transport: a role for intracellular glutathione. Mol Pharmacol 58:335-340, 2000.

24. Walters HC, Craddock AL, Fusegawa H, Willingham MC, Dawson PA. Expression, transport properties, and chromosomal location of organic anion transporter subtype 3. Am J Physiol (Lond) Gastrointest Liver Physiol 279:G1188-G1200, 2000.

25. Li N, Hartley DP, Cherrington NJ, Klaassen CD. Tissue expression, ontogeny, and inducibility of rat organic anion transporting polypeptide 4. J Pharmacol Exp Ther 301:551-560, 2002.

26. Kusuhara H, He Z, Nagata Y, Nozaki Y, Ito T, Masuda H, et al. Expression and functional involvement of organic anion transporting polypeptide subtype 3 (Slc21a7) in rat choroid plexus. Pharm Res 20:720-727, 2003.

27. Ohtsuki S, Takizawa T, Takanaga H, Hori S, Hosoya K, Terasaki $\mathrm{T}$, Localization of organic anion transporting polypeptide 3 (oatp3) in mouse brain parenchymal and capillary endothelial cells. J Neurochem 90:743-749, 2004

28. Cattori V, van Montfoort JE, Stieger B, Landmann L, Meijer DK, Winterhalter $\mathrm{KH}$, et al. Localization of organic anion transporting polypeptide 4 (Oatp4) in rat liver and comparison of its substrate specificity with Oatp1, Oatp2 and Oatp3. Pflugers Arch 443:188$195,2001$.

29. Abe T, Kakyo M, Tokui T, Nakagomi R, Nishio T, Nakai D, et al. Identification of a novel gene family encoding human liverspecific organic anion transporter LST-1. J Biol Chem 274:17159-17163, 1999.

30. Kullak-Ublick GA, Hagenbuch B, Stieger B, Schteingart CD, Hofmann AF, Wolkoff AW, et al. Molecular and functional characterization of an organic anion transporting polypeptide cloned from human liver. Gastroenterology 109:1274-1282, 1995.

31. Bossuyt X, Muller M, Meier PJ. Multispecific amphipathic substrate transport by an organic anion transporter of human liver. J Hepatol 25:733-738, 1996.

32. Leininger B, Ghersi-Egea JF, Siest G, Minn A. In vivo study of the elimination from rat brain of an intracerebrally formed xenobiotic metabolite, 1-naphthyl- $\beta$-D-glucuronide. J Neurochem 56 : 1163-1168, 1991.

33. Banks WA, Kastin AJ, Sam HM, Cao VT, King B, Maness LM, et al. Saturable efflux of the peptides RC-160 and Tyr-MIF-1 by different parts of the blood-brain barrier. Brain Res Bull 35:179182, 1994.

34. Kitazawa T, Terasaki T, Suzuki H, Kakee A, Sugiyama Y, Efflux of taurocholic acid across the blood-brain barrier: interaction with cyclic peptides, J Pharmacol Exp Ther 286:890-895, 1998.

35. Asaba H, Hosoya K, Takanaga H, Ohtsuki S, Tamura E, Takizawa T, et al. Blood-brain barrier is involved in the efflux transport of a neuroactive steroid, dehydroepiandrosterone sulfate, via organic anion transporting polypeptide 2. J Neurochem 75:1907-1916, 2000.

36. Hosoya K, Asaba H, Terasaki T. Brain-to-blood efflux transport of estrone-3-sulfate at the blood-brain barrier in rats. Life Sci 67:2699-2711, 2000.

37. Sugiyama D, Kusuhara H, Shitara Y, Abe T, Meier PJ, Sekine T, et al. Characterization of the efflux transport of $17 \beta$-estradiol-D$17 \beta$-glucuronide from the brain across the blood-brain barrier. J Pharmacol Exp Ther 298:316-322, 2001.

38. Sugiyama D, Kusuhara H, Shitara Y, Abe T, Sugiyama Y, Effect of $17 \beta$-estradiol-D-17 $\beta$-glucuronide on the rat organic anion transporting polypeptide 2-mediated transport differs depending on substrates. Drug Metab Dispos 30:220-223, 2002.

39. Schumacher M, Guennoun R, Robel P, Baulieu EE. Neurosteroids in the hippocampus: neuronal plasticity and memory. Stress 2:65-78, 1997.

40. Kawato S, Yamada M, Kimoto T. Brain neurosteroids are 4th generation neuromessengers in the brain: cell biophysical analysis of steroid signal transduction. Adv Biophys 37:1-48, 2003

41. Dagenais C, Ducharme J, Pollack GM. Uptake and efflux of the peptidic delta-opioid receptor agonist. Neurosci Lett 301:155$158,2001$. 
42. Hosoya K, Tetsuka K, Nagase K, Tomi M, Saeki S, Ohtsuki S, et al. Conditionally immortalized brain capillary endothelial cell lines established from a transgenic mouse harboring temperaturesensitive simian virus 40 large T-antigen gene. AAPS PharmSci 2:E27, 2000.

43. Li JY, Boado RJ, Pardridge WM. Blood-brain barrier genomics. $J$ Cereb Blood Flow Metab 21:61-68, 2001.

44. Sugiyama D, Kusuhara H, Taniguchi H, Ishikawa S, Nozaki Y, Aburatani $\mathrm{H}$, et al. Functional characterization of rat brain-specific organic anion transporter (Oatp14) at the blood-brain barrier: high affinity transporter for thyroxine. J Biol Chem 278:4348943495, 2003.

45. Tohyama K, Kusuhara H, Sugiyama Y. Involvement of multispecific organic anion transporter, Oatp14 (Slc21a14), in the transport of thyroxine across the blood-brain barrier. Endocrinology 145:4384-4391, 2004.

46. Pizzagalli F, Hagenbuch B, Stieger B, Klenk U, Folkers G, Meier PJ. Identification of a novel human organic anion transporting polypeptide as a high affinity thyroxine transporter. Mol Endocrinol 16:2283-2296, 2002.

47. Enomoto A, Kimura H, Chairoungdua A, Shigeta Y, Jutabha P, $\mathrm{Cha} \mathrm{SH}$, et al. Molecular identification of a renal urate anion exchanger that regulates blood urate levels. Nature 417:447-452, 2002.

48. Enomoto A, Wempe MF, Tsuchida H, Shin HJ, Cha SH, Anzai N, et al. Molecular identification of a novel carnitine transporter specific to human testis. Insights into the mechanism of carnitine recognition. J Biol Chem 277:36262-36271, 2002.

49. Koepsell H, Endou H. The SLC22 drug transporter family. Pflugers Arch 447:666-676, 2004.

50. Kusuhara H, Sekine T, Utsunomiya-Tate N, Tsuda M, Kojima R, $\mathrm{Cha} \mathrm{SH}$, et al. Molecular cloning and characterization of a new multispecific organic anion transporter from rat brain. $J$ Biol Chem 274:13675-13680, 1999.

51. Kikuchi R, Kusuhara H, Sugiyama D, Sugiyama Y. Contribution of organic anion transporter 3 (Slc22a8) to the elimination of p-aminohippuric acid and benzylpenicillin across the blood-brain barrier. J Pharmacol Exp Ther 306:51-58, 2003.

52. Mori S, Takanaga H, Ohtsuki S, Deguchi T, Kang YS, Hosoya K, et al. Rat organic anion transporter 3 (rOAT3) is responsible for brain-to-blood efflux of homovanillic acid at the abluminal membrane of brain capillary endothelial cells. J Cereb Blood Flow Metab 23:432-440, 2003.

53. Ohtsuki S, Asaba H, Takanaga H, Deguchi T, Hosoya K, Otagiri $\mathrm{M}$, et al. Role of blood-brain barrier organic anion transporter 3 (OAT3) in the efflux of indoxyl sulfate, a uremic toxin: its involvement in neurotransmitter metabolite clearance from the brain. J Neurochem 83:57-66, 2002.

54. Ohtsuki S, Kikkawa T, Mori S, Hori S, Takanaga H, Otagiri M, et al. Mouse reduced in osteosclerosis transporter functions as an organic anion transporter 3 and is localized at abluminal membrane of blood-brain barrier. J Pharmacol Exp Ther 309:12731281, 2004.

55. Nagata Y, Kusuhara H, Endou H, Sugiyama Y. Expression and functional characterization of rat organic anion transporter 3 (rOat3) in the choroid plexus. Mol Pharmacol 61:982-988, 2002.

56. Alebouyeh M, Takeda M, Onozato ML, Tojo A, Noshiro R, Hasannejad H, et al. Expression of human organic anion transporters in the choroid plexus and their interactions with neurotransmitter metabolites. J Pharmacol Sci 93:430-436, 2003.

57. Nagata Y, Kusuhara H, Hirono S, Endou H, Sugiyama Y. Carriermediated uptake of H2-receptor antagonists by the rat choroid plexus: involvement of rat organic anion transporter 3. Drug Metab Dispos 32:1040-1047, 2004.

58. Sweet DH, Chan LM, Walden R, Yang XP, Miller DS, Pritchard JB. Organic anion transporter 3 (Slc22a8) is a dicarboxylate exchanger indirectly coupled to the $\mathrm{Na}+$ gradient. Am J Physiol (Lond) Renal Physiol 284:F763-F769, 2003.

59. Sweet DH, Miller DS, Pritchard JB, Fujiwara Y, Beier DR, Nigam SK. Impaired organic anion transport in kidney and choroid plexus of organic anion transporter 3 (Oat3 (Slc22a8)) knockout mice. J Biol Chem 277:26934-26943, 2002.

60. Sugiyama D, Kusuhara H, Lee YJ, Sugiyama Y. Involvement of multidrug resistance associated protein 1 (Mrp1) in the efflux transport of $17 \beta$ estradiol-D-17 $\beta$-glucuronide (E217 $\beta$ G) across the blood-brain barrier. Pharm Res 20:1394-1400, 2003.

61. Hasegawa M, Kusuhara H, Endou H, Sugiyama Y. Contribution of organic anion transporters to the renal uptake of anionic compounds and nucleoside derivatives in rat. J Pharmacol Exp Ther 305:1087-1097, 2003.

62. Hasegawa M, Kusuhara H, Sugiyama D, Ito K, Ueda S, Endou H, et al. Functional involvement of rat organic anion transporter 3 (rOat3; Slc22a8) in the renal uptake of organic anions. J Pharmacol Exp Ther 300:746-753, 2002.

63. Kakee A, Terasaki T, Sugiyama Y. Selective brain to blood efflux transport of para-aminohippuric acid across the blood-brain barrier: in vivo evidence by use of the brain efflux index method. J Pharmacol Exp Ther 283:1018-1025, 1997.

64. Suzuki H, Sawada Y, Sugiyama Y, Iga T, Hanano M. Facilitated transport of benzylpenicillin through the blood-brain barrier in rats. J Pharmacobiodyn 12:182-185, 1989.

65. Mori K, Ogawa Y, Ebihara K, Aoki T, Tamura N, Sugawara A, et al. Kidney-specific expression of a novel mouse organic cation transporter-like protein. FEBS Lett 417:371-374, 1997.

66. Imaoka T, Kusuhara H, Adachi-Akahane S, Hasegawa M, Endou $\mathrm{H}$, Sugiyama Y. The renal-specific transporter mediates facilitative transport of organic anions at the brush border membrane of mouse renal tubules. J Am Soc Nephrol 15:2012-2022, 2004.

67. Breen CM, Sykes DB, Fricker G, Miller DS. Confocal imaging of organic anion transport in intact rat choroid plexus. Am J Physiol (Lond) Renal Physiol 282:F877-F885, 2002.

68. Kido Y, Tamai I, Ohnari A, Sai Y, Kagami T, Nezu J, et al. Functional relevance of carnitine transporter OCTN2 to brain distribution of L-carnitine and acetyl-L-carnitine across the blood-brain barrier. J Neurochem 79:959-969, 2001.

69. Tamai I, Ohashi R, Nezu J, Yabuuchi H, Oku A, Shimane M, et al. Molecular and functional identification of sodium ion-dependent, high affinity human carnitine transporter OCTN2. J Biol Chem 273:20378-20382, 1998.

70. Sekine T, Kusuhara H, Utsunomiya-Tate N, Tsuda M, Sugiyama Y, Kanai Y, et al. Molecular cloning and characterization of high-affinity carnitine transporter from rat intestine. Biochem Biophys Res Commun 251:586-591, 1998.

71. Tamai I, Ohashi R, Nezu JI, Sai Y, Kobayashi D, Oku A, et al. Molecular and functional characterization of organic cation/carnitine transporter family in mice. J Biol Chem 275:40064-40072, 2000.

72. Nezu J, Tamai I, Oku A, Ohashi R, Yabuuchi H, Hashimoto N, et al. Primary systemic carnitine deficiency is caused by mutations in a gene encoding sodium ion-dependent carnitine transporter. Nat Genet 21:91-94, 1999.

73. Inano A, Sai Y, Nikaido H, Hasimoto N, Asano M, Tsuji A, et al. Acetyl-L-carnitine permeability across the blood-brain barrier and involvement of carnitine transporter OCTN2. Biopharm Drug Dispos 24:357-365, 2003.

74. Yokogawa K, Higashi Y, Tamai I, Nomura M, Hashimoto N, Nikaido $\mathrm{H}$, et al. Decreased tissue distribution of L-carnitine in juvenile visceral steatosis mice. J Pharmacol Exp Ther 289:224230, 1999.

75. Ohashi R, Tamai I, Nezu Ji J, Nikaido H, Hashimoto N, Oku A, et al. Molecular and physiological evidence for multifunctionality of carnitine/organic cation transporter OCTN2. Mol Pharmacol 59:358-366, 2001.

76. Koepsell H, Gorboulev V, Arndt P. Molecular pharmacology of organic cation transporters in kidney. J Membr Biol 167:103-117, 1999.

77. Sweet DH, Miller DS, Pritchard JB. Ventricular choline transport: a role for organic cation transporter 2 expressed in choroid plexus. J Biol Chem 276:41611-41619, 2001.

78. Choudhuri S, Cherrington NJ, Li N, Klaassen CD. Constitutive expression of various xenobiotic and endobiotic transporter $\mathrm{mR}$ NAs in the choroid plexus of rats. Drug Metab Dispos 31:13371345, 2003

79. Zwart R, Verhaagh S, Buitelaar M, Popp-Snijders C, Barlow DP. Impaired activity of the extraneuronal monoamine transporter 
system known as uptake-2 in Orct3/Slc22a3-deficient mice. Mol Cell Biol 21:4188-4196, 2001.

80. Jonker JW, Wagenaar E, Mol CA, Buitelaar M, Koepsell H, Smit $\mathrm{JW}$, et al. Reduced hepatic uptake and intestinal excretion of organic cations in mice with a targeted disruption of the organic cation transporter 1 (Oct1 [Slc22a1]) gene. Mol Cell Biol 21: 5471-5477, 2001.

81. Jonker JW, Wagenaar E, Van Eijl S, Schinkel AH. Deficiency in the organic cation transporters 1 and 2 (Oct1/Oct2 [Slc22a1/ Slc22a2]) in mice abolishes renal secretion of organic cations. Mol Cell Biol 23:7902-7908, 2003.

82. Miller DS, Nobmann SN, Gutmann H, Toeroek M, Drewe J, Fricker G. Xenobiotic transport across isolated brain microvessels studied by confocal microscopy, Mol Pharmacol 58:1357-1367, 2000.

83. Zhang Y, Schuetz JD, Elmquist WF, Miller DW. Plasma membrane localization of multidrug resistance-associated protein (MRP) homologues in brain capillary endothelial cells. J Pharmacol Exp Ther 311:449-455.

83a. Leggas M, Adachi M, Scheffer GL, Sun D, Wielinga P, Du G, Mercer KE, Zhuang Y, Panetta JC, Johnston B, Scheper RJ, Stewart CF, Schuetz JD. Mrp4 confers resistance to topotecan and protects the brain from chemotherapy. Mol Cell Biol 24:7612$7621,2004$.

84. Cisternino S, Mercier C, Bourasset F, Roux F, Scherrmann JM. Expression, up-regulation, and transport activity of the multidrugresistance protein Abcg2 at the mouse blood-brain barrier. Cancer Res 64:3296-3301, 2004.

85. Hori S, Ohtsuki S, Tachikawa M, Kimura N, Kondo T, Watanabe $\mathrm{M}$, et al. Functional expression of rat ABCG2 on the luminal side of brain capillaries and its enhancement by astrocyte-derived soluble factor(s). J Neurochem 90:526-536, 2004.

86. Cooray HC, Blackmore CG, Maskell L, Barrand MA. Localisation of breast cancer resistance protein in microvessel endothelium of human brain. Neuroreport 13:2059-2063, 2002.

87. Sampath J, Adachi M, Hatse S, Naesens L, Balzarini J, Flatley RM, et al. Role of MRP4 and MRP5 in biology and chemotherapy. AAPS PharmSci 4:E14, 2002.

88. Doyle LA, Ross DD. Multidrug resistance mediated by the breast cancer resistance protein BCRP (ABCG2). Oncogene 22:73407358, 2003.

89. Haimeur A, Conseil G, Deeley RG, Cole SP. The MRP-related and BCRP/ABCG2 multidrug resistance proteins: biology, substrate specificity and regulation. Curr Drug Metab 5:21-53, 2004.

90. Suzuki H, Sugiyama Y. Excretion of GSSG and glutathione conjugates mediated by MRP1 and cMOAT/MRP2. Semin Liver Dis 18:359-376, 1998.
91. Muller M, Jansen PL. Molecular aspects of hepatobiliary transport. Am J Physiol (Lond) 272:G1285-G1303, 1997.

92. Russel FG, Masereeuw R, van Aubel RA. Molecular aspects of renal anionic drug transport. Annu Rev Physiol 64:563-594, 2002.

93. Mizuno N, Suzuki M, Kusuhara H, Suzuki H, Takeuchi K, Niwa $\mathrm{T}$, et al. Impaired renal excretion of 6-hydroxy-5,7-dimethyl-2methylamino-4-(3-pyridylmethyl) benzothiazole (E3040) sulfate in breast cancer resistance protein (Bcrp1/Abcg2) knockout mice. Drug Metab Dispos 32:898-901, 2004.

94. Sasaki M, Suzuki H, Ito K, Abe T, Sugiyama Y. Transcellular transport of organic anions across a double-transfected MadinDarby canine kidney II cell monolayer expressing both human organic anion-transporting polypeptide (OATP2/SLC21A6) and multidrug resistance-associated protein 2 (MRP2/ABCC2). J Biol Chem 277:6497-6503, 2002.

95. Cui Y, Konig J, Keppler D. Vectorial transport by double-transfected cells expressing the human uptake transporter SLC21A8 and the apical export pump ABCC2. Mol Pharmacol 60:934943, 2001.

96. Mita S, Suzuki H, Akita H, Stieger B, Meier PJ, Hofmann A, et al. Vectorial transport of bile salts across MDCK cells expressing both rat $\mathrm{Na}+$ /taurocholate cotransporting polypeptide and rat bile salt export pump. Am J Physiol (Lond) Gastrointest Liver Physiol 5 Aug 2004.

97. Cvetkovic M, Leake B, Fromm MF, Wilkinson GR, Kim RB. OATP and P-glycoprotein transporters mediate the cellular uptake and excretion of fexofenadine. Drug Metab Dispos 27:866871, 1999.

98. Jonker JW, Smit JW, Brinkhuis RF, Maliepaard M, Beijnen JH, Schellens JH, et al. Role of breast cancer resistance protein in the bioavailability and fetal penetration of topotecan. J Natl Cancer Inst 92:1651-1656, 2000.

99. Assem M, Schuetz EG, Leggas M, Sun D, Yasuda K, Reid G, et al. Interactions between hepatic Mrp4 and Sult2a as revealed by the constitutive androstane receptor and Mrp4 knockout mice. J Biol Chem 279:22250-22257, 2004.

100. Adachi Y, Suzuki H, Sugiyama Y. Comparative studies on in vitro methods for evaluating in vivo function of MDR1 P-glycoprotein. Pharm Res 18:1660-1668, 2001.

101. Hoffmeyer S, Burk O, von Richter O, Arnold HP, Brockmoller J, Johne A, et al. Functional polymorphisms of the human multidrug-resistance gene: multiple sequence variations and correlation of one allele with P-glycoprotein expression and activity in vivo. Proc Natl Acad Sci USA 97:3473-3478, 2000.

102. Fromm MF, The influence of MDR1 polymorphisms on P-glycoprotein expression and function in humans. Adv Drug Deliv Rev 54:1295-1310, 2002. 